\title{
UJI KESESUAIAN EMPAT ISOLAT TRICHODERMA SPP. DAN DAYA HAMBAT IN VITRO TERHADAP BEBERAPA PATOGEN TANAMAN
}

\author{
Loekas Soesanto ${ }^{1}$, Endang Mugiastuti', Ruth Feti Rahayuniati ${ }^{1}, \&$ Ratna Stia Dewi ${ }^{2}$ \\ ${ }^{1}$ Fakultas Pertanian dan ${ }^{2}$ Fakultas Biologi, Universitas Jenderal Soedirman \\ Jl. dr. Suparno, Karangwangkal, Purwokerto 53123 \\ E-mail: lukassus26@gmail.com
}

\begin{abstract}
Compatibility test of four Trichoderma spp. Isolates and in vitro inhibition ability on several plant pathogens. In vitro descriptive compatibility research was carried out to know the compatibility among Trichoderma spp. isolates and their inhibition ability toward several plant pathogens. Four Trichoderma spp. isolates used were ginger, shallot, banana, and pineapple isolates; while the pathogens used were pathogenic fungi (Fusarium, Colletotrichum, Phytophthora, and Sclerotium), bacteria (Ralstonia), and nematode (Meloidogyne dan Globodera). Observation was done toward inhibition zone between Trichoderma spp. isolates, colony radial growth, mycelial dry weight, and nematode mortality. Result of the research indicated that the four Trichoderma spp. isolates were compatible and no growth inhibition was observed. The inhibition ability of all Trichoderma spp. isolates varied and the ginger isolate had the highest inhibition ability and mortality on all fungal species and the nematodes, while on the pathogenic bacteria there was no inhibition.
\end{abstract}

Key words: compatibility, inhibition ability, plant pathogens, Trichoderma spp. isolates

\begin{abstract}
ABSTRAK
Uji kesesuaian empat isolat Trichoderma spp. dan daya hambat in vitro terhadap beberapa patogen tanaman. Penelitian deskripsi in vitro dilakukan untuk mengetahui kesesuaian antar-isolat Trichoderma spp. dan uji daya hambatnya terhadap beberapa patogen tanaman. Empat isolat Trichoderma spp. digunakan, yaitu isolat jahe, bawang merah, pisang, dan nenas; sedangkan patogen tanaman yang digunakan antara lain dari kelompok jamur (Fusarium, Colletotrichum, Phytophthora, dan Sclerotium), bakteri (Ralstonia), dan nematoda (Meloidogyne dan Globodera) patogen. Pengamatan dilakukan terhadap ada tidaknya zona hambatan antar-isolat Trichoderma sp., pertumbuhan jejari koloni, dan berat kering miselium untuk jamur patogen serta tingkat mortalitas untuk nematoda patogen. Hasil penelitian menunjukkan bahwa keempat isolat Trichoderma spp. yang digunakan mempunyai kesesuaian, tidak terdapat penghambatan pertumbuhan. Daya hambat keempat isolat Trichoderma spp. beragam dan isolat jahe mempunyai daya hambat dan mortalitas tertinggi terhadap semua spesies jamur dan nematoda patogen, sedangkan bakteri patogen tidak ada penghambatan.
\end{abstract}

Kata kunci: daya hambat, isolat Trichoderma spp., kesesuaian, patogen tanaman

\section{PENDAHULUAN}

Patogen tanaman banyak menjadi masalah penting di dalam budidaya tanaman, karena dapat menurunkan produksi tanaman (Champoiseau et al., 2009). Banyak usaha telah dilakukan untuk mengendalikan patogen tanaman, baik dengan penggunaan tanaman tahan maupun pestisida sintetis. Akan tetapi, tanaman tahan terhadap patogen tanaman jarang tersedia, sedangkan pestisida sintetis jika digunakan dengan tidak bijaksana akan banyak menimbulkan masalah, baik terhadap lingkungan, produk tanaman, maupun kesehatan manusia. Oleh karena itu, agensia pengendali hayati merupakan salah satu pilihan pengendalian patogen tanaman yang menjanjikan karena murah, mudah didapat, dan aman terhadap lingkungan.

Trichoderma sp. merupakan salah satu agensia pengendali hayati yang telah banyak digunakan untuk mengendalikan mikroba patogen tanaman (Elad et al., 1982; Sharon et al., 2001; Soesanto et al., 2005). Eksplorasi agensia pengendali hayati selain Trichoderma spp. telah banyak dilakukan, dan pada umumnya ditemukan banyak mikroba dari kelompok jamur (Soesanto et al., 2011a). Penggunaannya secara tunggal atau gabungan telah juga diteliti, dan umumnya penggunaan secara gabungan lebih efektif dibandingkan secara tunggal (Kloepper et al., 1997; Raupach \& Kloepper, 1998; Soesanto, 2000). 
Jamur antagonis $T$. harzianum isolat jahe dapat digabung dengan serbuk daun cengkeh untuk mengendalikan penyakit busuk rimpang pada jahe yang disebabkan oleh F. oxysporum f.sp. zingiberi (Soesanto et al., 2005). Penggunaan T. harzianum isolat jahe juga mampu menekan perkembangan penyakit layu Fusarium pada jahe (Amalia et al., 2004; Soesanto et al., 2005), kencur (Prabowo et al., 2006), bibit pisang Ambon Kuning (Soesanto \& Rahayuniati, 2009), pisang (Ivayani et al., 2013), subang bunga gladiol (Wardhana et al., 2009), dan bawang merah (Latifah et al., 2012), serta penyakit blas pada padi (Waluyo et al., 2005). Sementara itu, Trichoderma sp. isolat pisang mampu menekan penyakit busuk hati pada bibit pisang (Haryono et al., 2008). Isolat $T$. harzianum lain mampu menekan perkembangan penyakit busuk pangkal batang lada karenaPhytophthora capsisi (Ginting \& Maryono, 2012) dan mampu menekan penyakit layu fusarium pada tanaman tomat di rumah kaca (Rahayuniati \& Mugiastuti, 2009).

Keberadaan beberapa isolat Trichoderma spp. yang telah dieksplorasi belum pernah dilakukan uji antagonis terhadap berbagai patogen tanaman. Selain itu, antar-isolat Trichoderma spp. belum diketahui kesesuaiannya, sehingga belum dapat diketahui penggunaannya secara gabungan. Oleh karena itu, dilakukan penelitian ini dengan tujuan untuk mengetahui kesesuaian antar-isolat Trichoderma spp. dan uji daya hambatnya terhadap beberapa patogen tanaman, dari golongan jamur, bakteri, dan nematoda.

\section{METODE PENELITIAN}

Penyiapan Isolat Antagonis. Isolat jamur antagonisTrichoderma spp. yang digunakan adalah isolat jahe (Soesanto et al., 2005), pisang (Haryono et al., 2008), nenas (koleksi L. Soesanto), dan bawang merah (Santoso et al., 2007). Masing-masing isolat ditumbuhkan pada medium PDA (Tuite, 1969) dan diinkubasi pada suhu kamar selama 5-7 hari di Laboratorium Perlindungan Tanaman, Fakultas Pertanian, Universitas Jendral Soedirman, Purwokerto, untuk kemudian digunakan dalam penelitian ini.

Penyiapan Isolat Patogen. Jamur patogen yang diuji meliputi Fusarium sp., Phytophthora sp., Colletotrichum capsici, Pythium sp.,dan Sclerotium rolfsii (koleksi L. Soesanto dan Laboratorium Perlindungan Tanaman, Fakultas Pertanian, Universitas Jenderal Soedirman). Patogen tersebut masing-masing ditumbuhkan pada medium PDA yang diperkaya dengan
100 mg streptomisin sulfat (Sigma) (Papavizas, 1967) untuk Fusarium sp.,Colletotrichum capsici,Pythium sp., dan Sclerotium rolfsii serta medium V8 Jus untuk Phytophthora sp. (Tuite, 1969). Bakteri patogen yang diuji yaitu Ralstonia solanacearumyang ditumbuhkan pada medium NA (French et al., 1995), diinkubasi pada suhu kamar selama 2-3 hari. Nematoda yang diuji adalah Meloidogyne sp.dan nematoda sista kentang, yang diperoleh dari tanah sekitar tanaman kentang.

\section{Pengujian Kesesuaian Antar-isolat Trichoderma} spp. Pengujian dilakukan dengan menumbuhkan secara bersama Trichoderma spp. tersebut pada medium PDA dalam cawan Petri, dan diulang lima kali. Variabel yang diamati adalah ada tidaknya zona hambat. Apabila tidak terbentuk zona hambat, hal ini menunjukkan bahwa mikroba antagonis yang diuji saling sesuai dan dapat digabungkan.

Pengujian Daya Hambat. Pengujian daya hambat Trichoderma spp. terhadap masing-masing patogen dilakukan dengan metode dual culture. Setiap antagonis Trichoderma spp. pada medium PDA dipotong dengan diameter $5 \mathrm{~mm}$ diletakkan pada bagian tepi cawan Petri dengan jarak $3 \mathrm{~cm}$, kemudian diinkubasi selama 3 hari pada suhu kamar. Setiap cawan Petri diinokulasi dengan masing-masing patogen berdiameter $5 \mathrm{~mm}$ dan diletakkan $3 \mathrm{~cm}$ dari antagonis (Evans et al., 2003). Perlakuan tersebut diulang sebanyak 5 kali. Cawan Petri kemudian diinkubasi selama 3 hari pada suhu kamar. Pertumbuhan patogen dicatat dan data diperoleh dari persentase penghambatan pertumbuhan jejari dengan rumus:

dengan:

$$
\mathrm{PP}=\frac{\mathrm{R} 1-\mathrm{R} 2}{\mathrm{R} 1} \times 100
$$

$\mathrm{PP}=$ Penghambatan pertumbuhan $(\%)$

$\mathrm{R} 1=$ pertumbuhan jejari patogen kontrol, dan

R2 = pertumbuhan jejari patogen dalam dual culture dengan antagonis (Royse \& Ries, 1977).

Selanjutnya, di akhir pengamatan dilakukan penghitungan berat kering miselium jamur patogen (Lilly \& Barnett, 1951; Sutton \& Starzyk, 1972). Selain itu, juga diamati mortalitas nematode akibat perlakuan dengan Trichoderma spp.

Analisis Data. Data dianalisis secara deskriptif untuk uji kesesuaian antar-isolat Trichoderma spp. dan uji daya hambat. 


\section{HASIL DAN PEMBAHASAN}

Uji KesesuaianAntar-Isolat Trichoderma spp. Berdasarkan uji kesesuaian antar-isolat Trichoderma spp., yaitu isolat bawang merah, jahe, pisang, dan nenas, semua isolat yang ditumbuhkan bersama pada tempat yang sama tidak ada yang saling menghambat. Hal ini menunjukkan bahwa semua isolat Trichoderma spp. Adalah sesuai satu dengan yang lain (Tabel 1).

Keempat isolat Trichodermas spp. yang digunakan diduga mempunyai sifat dan ciri-ciri yang sama atau hamper sama, termasuk juga kemampuannya di dalam menghasilkan senyawa metabolit sekunder. Hal ini sesuai dengan hasil penelitian Soesanto et al. (2011b), yang menyatakan bahwa sifat morfologi dan fisiologi empat isolat Trichoderma spp. adalah sama. Hasil penelitian Gomez et al. (1997) menunjukkan bahwa pengamatan langsung secara makroskopis terhadap semua isolat Trichoderma spp. sangat mirip laju pertumbuhan jejari, pola pensporaan dan warna spora, dan tidak ada isolat yang tumbuh saling menutupi. Pendapat tersebut sesuai dengan hasil penelitian yng menunjukkan pertumbuhan keempat isolat Trichoderma spp. yang diuji tidak saling menghambat (Gambar 1).

Tidak adanya perbedaan di dalam kemampuan menghambat dari keempat isolat tersebut berkaitan erat dengan sifat genetikanya. Pasangan strain Trichoderma yang sesuai secara vegetatif dan peleburan protoplas memperlihatkan kesesuaian sederhana yang terbatas. Keterbatasan kesesuaian menurunkan sifat penggabungan ulang paraseksual tetapi tidak menghasilkan kemungkinan manipulasi genetikanya oleh peleburan protoplas (Stasz et al., 1989).

Uji Daya Hambat Isolat Trichoderma spp. Berdasarkan kemampuan penghambatannya, semua isolat Trichoderma spp. yang dicoba mempunyai kemampuan menghambat semua patogen tanaman yang diuji, kecuali terhadap bakteri patogen (Tabel 2). Hal ini ditunjukkan dengan daya hambat yang beragam untuk masing-masing patogen dan isolat Trichoderma spp.

Penghambatan Trichoderma spp. isolat pisang,bawang merah, jahe, dan nenas terhadap masingmasing patogen jamur dan nematoda berkisar antara

Tabel 1. Kesesuaian antar-isolat Trichoderma spp.

\begin{tabular}{lcccc}
\hline \multicolumn{1}{r}{ Isolat Trichoderma spp. } & Bawang merah & Jahe & Pisang & Nenas \\
\hline Bawang merah & + & + & + & + \\
Jahe & + & + & + & + \\
Pisang & + & + & + & + \\
Nenas & + & + & + & + \\
\hline
\end{tabular}

$+=$ sesuai/kompatibel; - = tidak sesuai.

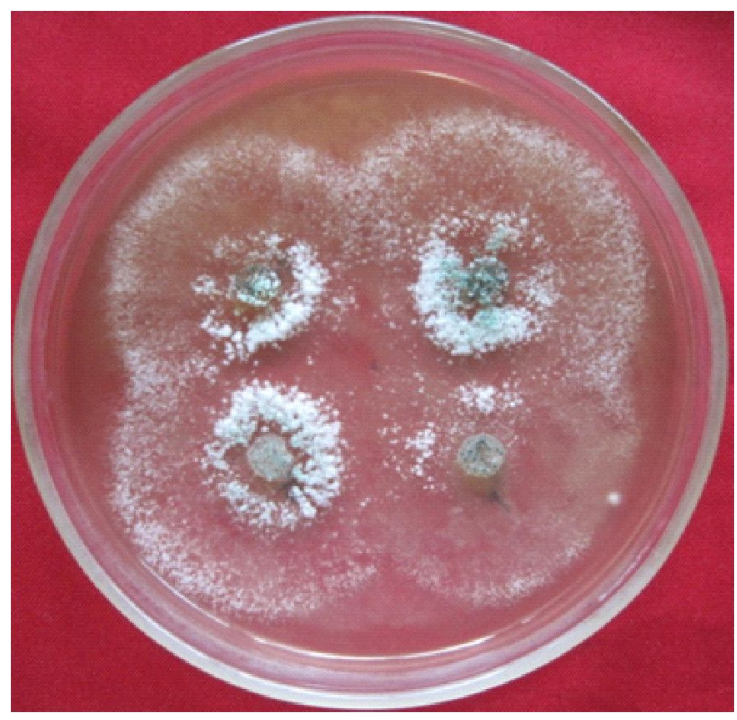

Gambar 1. Uji konfrontasi langsung empat isolat Trichoderma spp. 
$33,33-62,46 \%, 20,50-67,76 \%, 29,53-64,44 \%$, dan $22,26-65,56 \%$ untuk jamur patogen dan $81,69-233,3 \%$, $64,72-166,7 \%, 76,34-200,0 \%$, dan $68,39-156,7 \%$ untuk nematoda patogen. Berdasarkan Tabel 2 tampak bahwa masing-masing isolat Trichoderma spp. mempunyai daya hambat yang berbeda terhadap masingmasing patogen tanaman. Terhadap jamur patogen Fusarium, Trichoderma spp. isolat nenas nampak yang terbaik daya hambatnya, yang ditunjukkan dengan daya hambat tertinggi sebesar $61,82 \%$, sedangkan pada patogen Colletotrichum, isolat pisang yang menunjukkan daya hambat tertinggi, yaitu sebesar $33,33 \%$. Trichoderma spp. isolat pisang menunjukkan daya hambat tinggi terhadap patogen Phytophthora, dan isolat bawang merah terbaik daya hambatnya terhadap Sclerotium.

Kemampuan isolat Trichoderma spp. di dalam menghambat pertumbuhan isolat jamur patogen dipengaruhi oleh kemampuannya bertindak sebagai antagonis, dengan mekanisme yang dimiliki, seperti persaingan dan antibiosis. Gomez et al. (1997) menduga bahwa perbedaan kemampuan Trichoderma spp. adalah karena belum diketahuinya faktor pembatas yang berpengaruh terhadap banyak proses yang dapat menuju kepada keragaman. Sementara itu, Goes et al. (2002) dan Samuels et al. (2002) menyatakan bahwa keragaman antar-isolat Trichoderma spp. sangat tinggi dan tidak ada hubungannya antar-polimorfisme yang dijumpai dalam isolat tersebut. Hasil penelitian Latifah et al. (2012) juga mendukung adanya keragaman kemampuan masing-masing isolat Trichoderma spp. yang dicoba.

Kemampuan masing-masing isolat Trichoderma spp. di dalam menghambat pertumbuhan jamur patogen in vitro diperlihatkan pada Tabel 3, kaitannya dengan perbedaan berat kering jamur patogen. Pada Tabel 3 nampak bahwa dibandingkan kontrol, berat kering miselium jamur patogen mengalami penurunan akibat penghambatan oleh isolat Trichoderma spp.

Apabila dilihat rerata berat kering masing-masing jamur patogen, penurunan berat kering tertinggi terjadi karena Trichoderma spp. isolat jahe pada semua jamur patogen, yaitu sebesar 39,7, 84,9, 83,3, dan 85,4\% masing-masing untuk jamur Fusarium, Colletotrichum, Phytophthora, dan Sclerotium, dibandingkan dengan isolat Trichoderma spp. lainnya. Penurunan tertinggi berat kering karena Trichoderma spp. isolat jahe terjadi pada jamur Sclerotium. Sementara itu, isolat Trichoderma spp. lainnya juga mampu menurunkan berat kering miselium jamur patogen, namun penurunan terkecil terjadi pada jamur Sclerotium, khususnya pada isolat bawang merah dan pisang, dibandingkan dengan jamur patogen lain. Adanya perbedaan kemampuan antar-isolat Trichoderma di dalam menghambat pertumbuhan dan berat kering miselium jamur patogen diduga disebabkan oleh keragaman yang tinggi antar-

Tabel 2. Kemampuan menghambat Trichoderma spp. terhadap perkembangan patogen jamur dan bakteri serta mortalitas nematode dibandingkan kontrol

\begin{tabular}{lcccc}
\hline \multirow{2}{*}{ Patogen } & \multicolumn{4}{c}{ Kemampuan menghambat Trichoderma $(\%)$} \\
\cline { 2 - 5 } & Isolat pisang & Isolat bawang merah & Isolat jahe & Isolat nenas \\
\hline Fusarium & 41,76 & 39,12 & 57,54 & 61,82 \\
Colletotrichum & 33,33 & 20,50 & 29,53 & 22,26 \\
Phytophthora & 60,40 & 59,44 & 52,54 & 28,15 \\
Sclerotium & 62,46 & 67,78 & 64,44 & 65,56 \\
Ralstonia & 0,00 & 0,00 & 0,00 & 0,00 \\
Meloidogyne & 81,69 & 84,72 & 76,34 & 68,39 \\
Globodera & 233,3 & 166,7 & 200,0 & 156,7 \\
\hline
\end{tabular}

Tabel 3. Rerata berat kering miselium jamur patogen akibat perlakuan Trichoderma spp.

\begin{tabular}{lccccc}
\hline \multirow{2}{*}{\multicolumn{1}{c}{ Patogen }} & \multirow{2}{*}{ Kontrol } & \multicolumn{3}{c}{ Berat kering miselium patogen pada perlakuan Trichoderma (mg) } \\
\cline { 3 - 6 } & & Isolat pisang & Isolat bawang merah & Isolat jahe & Isolat nenas \\
\hline Fusarium & 0,0664 & 0,05 & 0,03 & 0,04 & 0,04 \\
Colletotrichum & 0,0662 & 0,02 & 0,03 & 0,01 & 0,02 \\
Phytophthora & 0,1195 & 0,06 & 0,07 & 0,02 & 0,03 \\
Sclerotium & 0,0961 & 0,05 & 0,08 & 0,01 & 0,04 \\
\hline
\end{tabular}


isolat Trichoderma, yang sesuai dengan pendapat Samuels et al. (2002).

Kemampuan yang tinggi dari Trichoderma spp. isolat jahe di dalam menghambat Sclerotium sesuai dengan pendapat Elad et al. (1982), yang menyatakan bahwa $T$. harzianum mensekresikan enzim $\beta-1,3-$ glukanase dan kitinase pada dinding sel patogen Sclerotium rolfsii sebagai sumber karbon utamanya. Lebih lanjut dikemukakan, bahwa aktivitas enzim lipase dan kitinase ditemukan ketika antagonis menyerang miselium S. rofsii. Selain itu, T. harzianum juga mengeluarkan enzim hidrolisis yang berbeda ketika menyerang miselium jamur patogen $S$. rolfsii, Rhizoctonia solani, dan Pythium aphanidermatum di dalam tanah.

Trichoderma spp. isolat jahe terbukti mempunyai kemampuan penghambatan lebih baik terhadap jamur patogenin vitro dibandingkan isolat lainnya.Hal ini didukung oleh beberapa penelitian yang telah dilakukan, seperti Soesanto et al. (2005), Waluyo et al. (2005), Prabowo et al. (2006), dan Wardhana et al. (2009) masing-masing terhadap penyakit layu Fusarium pada tanaman jahe, penyakit utama tanaman padi, penyakit layu fusarium pada tanaman kencur, dan penyakit layu Fusarium pada tanaman bunga gladiol.

Sementara itu, semua isolat Trichoderma spp. mempunyai daya hambat atau mortalitas terhadap telur nematoda yang diuji, dan yang tertinggi daya hambatnya ditunjukkan oleh isolat pisang, yaitu 81,69 dan 233,3\% masing-masing untuk Meloidogyne dan Globodera (Tabel 2). Kemampuan Trichoderma spp. di dalam mengendalikan nematoda patogen tanaman diduga disebabkan oleh kemampuannya menghasilkan enzim, yang dapat melisiskan dinding sel telur nematoda. Hal ini sesuai dengan pernyataan Sharon et al. (2001) dan Szabo et al. (2013), yang menyatakan bahwa semua strain Trichoderma memperlihatkan kemampuan mengkoloni telur dan juvenil stadium dua Meloidogyne javanica dalam uji in vitro steril, serta mempenetrasi massa telur. Hal ini karena peran enzim protease dari Trichoderma spp. yang berfungsi sama seperti nematisida.

PemanfaatanTrichoderma spp. mempunyai potensi baik untuk diaplikasikan karena kemampuannya di dalam menghambat pertumbuhan dan perkembangan patogen, khususnya jamur dan nematoda. Namun demikian, perbedaan dan keragaman antar-isolat Trichoderma spp. di dalam menghambat pertumbuhan patogen menjadi kendala di dalam aplikasi antagonis di lapangan. Kajian keragaman antar-isolat ini penting dilakukan untuk lebih mengetahui sifat dan daya hambatnya. Sementara itu, kesesuaian antar-isolat
Trichoderma spp. dapat digunakan untuk penggabungan isolat dalam aplikasinya, agar dapat diperoleh peningkatan daya kelolanya terhadap patogen tanaman.

\section{SIMPULAN}

Keempat isolat Trichoderma spp. yang digunakan mempunyai kesesuaian, atau dengan kata lain terdapat penghambatan pertumbuhan. Daya hambat keempat isolat Trichoderma spp. beragam dan isolat jahe mempunyai daya hambat dan mortalitas tertinggi terhadap semua spesies jamur dan nematoda patogen yang diuji, sedangkan bakteri patogen tidak mengalami penghambatan.

\section{SANWACANA}

Penelitian ini merupakan bagian dari penelitian utama yang didanai dari Hibah Kompetensi Batch I Tahun 2013, Direktorat Perguruan Tinggi, Kementerian Pendidikandan Kebudayaan; untuk itu diucapkan terimakasih untuk dukungan finansialnya. Terimakasih juga disampaikan kepada Sri Utari Fahila, Tita Siti Nurhasanah, Anggit An Nashirul, dan Chairul Basir atas semua bantuan teknisnya.

\section{DAFTAR PUSTAKA}

Amalia R, Djatmiko HA, \& Soesanto L. 2004. Potensi beberapa antagonis dalam menekan Fusarium oxysporum Schlecht. f.sp. zingiberi Trujillo pada tanaman jahe. Dalam: L. Soesanto (Ed.), Prosiding Simposium Nasional I tentang Fusarium. Hlm.301-312.Purwokerto, 26-27 Agustus 2004.

Champoiseau PG, Jones JB, \& Allen C. 2009. Ralstonia solanacearum race 3 biovar 2 causes tropical losses and temperate anxieties. Online Plant Health Progress. DOI: 10.1.94/PHP-2009-031301-RV.

Elad Y, Chet I, \& Henis Y. 1982. Degradation of plant pathogenic fungi by Trichoderma harzianum. Canadian Journal of Microbiology 28(7): 719725. Doi: $10.1139 / \mathrm{m} 82-110$.

Evans HC, Holmes KA, \& Thomas SE. 2003. Endophytes and mycoparasites associated with an indigenous forest Tree, Theobroma gileri, in Ecuador and a preliminary assessment of their potential as biocontrol agents of cocoa diseases. Mycological progress 2: 149-160. 
French EB, Gutarra L, Aley P, \& Elphinstone J. 1995. Culture media for Ralstonia solanacearum isolation, identification, and maintenance. Fitopatologia 30(3): 126-130. (On-line). http:// www.cipotato.org/Training/Materials/Bacterial/ Bacterial8.PDF diakses 1 November 2013.

Ginting C \& Maryono T. 2012. Penurunan keparahan penyakit busuk pangkal batang pada lada akibat aplikasi bahan organik dan Trichoderma harzianum. J. HPT Tropika 12(2): 162-168.

Goes LB, da Costa ABL, de Carvalho Freire LL, \& de Oliveira NT. 2002. Randomly amplified polymorphic DNA of Trichoderma isolates and antagonism against Rhizoctonia solani.Braz. Arch. Biol. Technol. 45(2): 151-160.

Gomez I, Chet I, \& Herrera-Estrella A. 1997. Genetic diversity and vegetative compatibility among Trichoderma harzianum isolates. Mol. Gen. Genet. 256: 127-135.

Haryono J, Prihatiningsih N, Wardhana RA, \& Soesanto L. 2008. Pengaruh pemasteuran tanah tunggal atau digabung agensia hayati terhadap penyakit busuk hati di pembibitan pisang. Agrin 12(2): 199211.

Ivayani, Ginting C, \& Yusnita. 2013. Aplikasi Trichoderma spp. dan bahan organik untuk pengendalian hayati penyakit layu fusarium (Fusarium oxysporum f. sp. cúbense) pada tanaman pisang. Makalah disampaikan pada Seminar dan Kongres Nasional ke-XXII Perhimpunan Fitopatologi Indonesia, Padang, 7-10 Oktober 2013.

Kloepper JW, Tuzun S, Zehnder GW, \& Wei G. 1997. Multiple disease protection by rhizobacteria that induce systemic resistance-historical precedence. Phytopathology 87(2): 136-137.

Latifah A, Kustantinah, \& Soesanto L. 2012. Pemanfaatan beberapa isolat Trichoderma harzianum sebagai agensia pengendali hayati penyakit layu Fusarium pada bawang merah in Planta. Eugenia 17(5): 86-94.

Lilly VG \& Barnett HL. 1951. Physiology of theFungi. McGraw-Hill Book Co., Inc., New York.

Papavizas GC. 1967. Evaluation of various media and anti-microbial agents for isolation of Fusarium from soil.Phytopathology 57(8): 848-852.
Prabowo AKE, Prihatiningsih N, \& Soesanto L. 2006. Potensi Trichoderma harzianum dalam mengendalikan Sembilan isolat Fusarium oxysporum Schlecht.f.sp. zingiberi Trujillo pada kencur. Jurnal Ilmu-IlmuPertanian Indonesia 8(2): 76-84.

Rahayuniati RF. \& Mugiastuti E. 2009. Pemanfaatan jamur antagonis dan pupuk organik untuk mengendalikan penyakit layu Fusrium tomat. Jurnal Pembangunan Pedesaan 9(1): 25-34.

Raupach GS \& Kloepper JW. 1998. Mixture of plant growth-promoting rhizobacteria enhance biological control of multiple cucumber pathogens. Phytopathol. 88: 1158-1164.

Royse DJ \& Ries SM.1977. The influence of fungi isolated from peach twigs on the pathogenicity of Cytosporacinata. Phytopathol. 63: 603-607.

Samuels GJ, Dodd SL, Gams W, Castlebury LA, \& Petrini O. 2002. Trichoderma species associated with the green mold epidemic of commercially grown Agaricus bisporus. Mycologia 94(1): 146-170.

Santoso SE, Soesanto L, \& Haryanto TAD. 2007. Penekanan hayati penyakit moler pada bawang merah dengan Trichoderma harzianum, Trichoderma koningii, dan Pseudomonas fluorescens P60. J. HPT Tropika 7(1): 53-61.

Sharon E, Bar-Eyal M, Chet I, Herrera-Estrella A, Kleifeld O, \& Spiegel Y. 2001. Biological control of the root-knot nematode Meloidogyne javanica by Trichoderma harzianum. Phytopathology 91(7): 687-693.

Soesanto L. 2000. Ecological and Biological Control of Verticillium dahliae. [Thesis]. Wageningen University, Wageningen.120 p.

Soesanto L \& Rahayuniati RF. 2009. Pengimbasan ketahanan bibit pisang Ambon Kuning terhadap penyakit layu fusarium dengan beberapa jamura ntagonis. J. HPT Tropika 9(2): 130-140.

Soesanto L, Soedharmono, Prihatiningsih N, Manan A, Iriani E, \& Pramono J. 2005. Potensi agensia hayati dan nabati dalam mengendalikan penyakit busuk rimpang jahe. J. HPT Tropika 5(1): 5057. 
Soesanto L, Mugiastuti E, \& Rahayuniati RF. 2011a. Inventarisasi dan identifikasi patogen tular-tanah pada pertanaman kentang di Kabupaten Purbalingga. J Hort. 21(3): 254-264.

Soesanto L, Utami DS, \& Rahayuniati RF. 2011b. Morphological characteristics of four Trichoderma isolates and two endophytic Fusarium isolates. Can J Sci. and Industrial Res. 2(8): 294-304.

Stasz TE, Harman GE, \& Gullino ML. 1989. Limited vegetative compatibility following intra- and interspecific protoplast fusion in Trichoderma. Experim. Mycol. 13(4): 364-371.

Sutton III LM \& Starzyk MJ. 1972. Procedure and analysis of a useful method in determining mycelia dry weight from agar plates. Appl. Microbiol. 24(6): 1011-1012.
Szabó M, Urbán P, Virányi F, Kredics L, \& Fekete C. 2013. Comparative gene expression profiles of Trichoderma harzianum proteases during in vitro nematode egg-parasitism. Biological Control 67(3): 337-343.

Tuite J. 1969.Plant Pathological Methods: Fungi and Bacteria. Burgess Publ. Co., Minneapolis, Minnesota.

Waluyo KA, Soesanto L, \& Djatmiko HA. 2005. Keefektifan tebukonazol dan Trichoderma harzianum tunggal atau gabungan terhadap tiga penyakit penting karena jamur pada padi sawah. Tropika 13(2): 128-136.

Wardhana DW, Soesanto L, \& Utami DS. 2009. Penekanan hayati penyakit layu fusarium pada subang gladiol. J. Hortikultura 19(2): 304-311. 